\title{
Water History \\ An investigation into the age and origin of Suranga in the foothills of the Western Ghats of India \\ --Manuscript Draft--
}

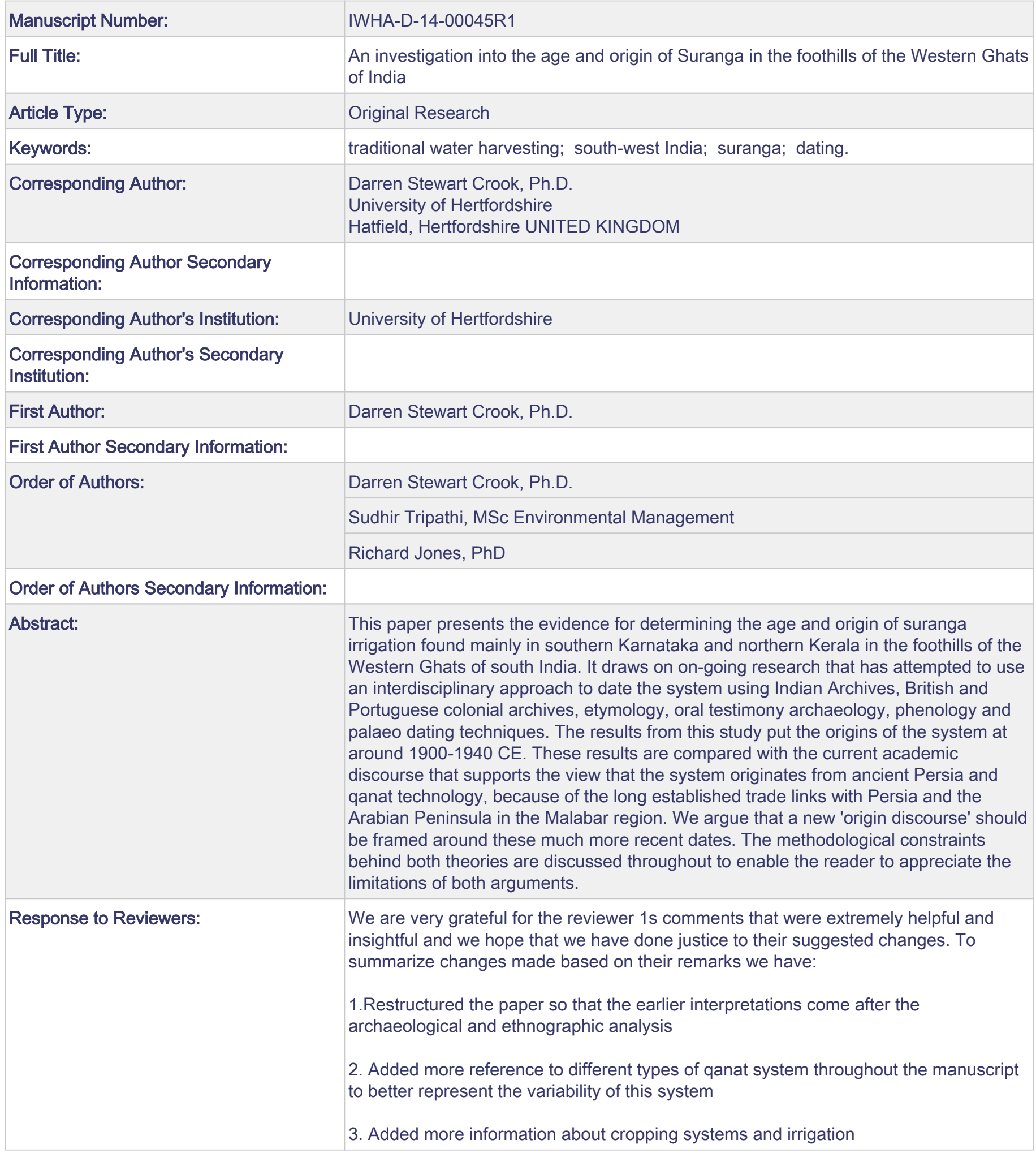


1

Author 1 (for correspondence d.crook@herts.ac.uk)

DARREN CROOK Department of Human and Environmental Sciences, University of Hertfordshire, UK

Author 2

SUDHIR TRIPATHI Department of Human and Environmental Sciences, University of Hertfordshire, UK

Author 3

RICHARD JONES School of Geography, University of Exeter, UK 
An investigation into the age and origin of Suranga in the foothills of the Western Ghats of India

\begin{abstract}
This paper presents the evidence for determining the age and origin of suranga irrigation found mainly in southern Karnataka and northern Kerala in the foothills of the Western Ghats of south India. It draws on on-going research that has attempted to use an interdisciplinary approach to date the system using Indian Archives, British and Portuguese colonial archives, etymology, oral testimony archaeology, phenology and palaeo dating techniques. The results from this study put the origins of the system at around 1900-1940 CE. These results are compared with the current academic discourse that supports the view that the system originates from ancient Persia and qanat technology, because of the long established trade links with Persia and the Arabian Peninsula in the Malabar region. We argue that a new 'origin discourse' should be framed around these much more recent dates. The methodological constraints behind both theories are discussed throughout to enable the reader to appreciate the limitations of both arguments.
\end{abstract}

\title{
Introduction
}

Suranga are found in the foothills of the Western Ghats of India mainly in the districts of Dakshin Kannada in Karnataka and Kasaragod in Kerala (Figure 1). The definition of suranga used here is that of a manmade horizontal adit or tunnel system constructed in order to capture and extract near to surface phreatic ground waters that are used for drinking water and irrigation (Figure 2). The system is found only in areas with laterite soils that are of sufficient strength to facilitate safe tunnelling to connect with a nearby phreatic water table. Unexposed laterite is porous which increases the water holding capacity. As rainwater percolates through the porous laterite it mixes with biotic matter at the top of the soil column and becomes acidic removing the calcium deposits of the lower horizon, this results in the formation of vacuities (Kokkal, 2002). The rainwater is stored in these vacuities which form the underground reservoir of water. It is worth noting that the properties of laterite vary greatly geographically (Sutapa Das, 2007) and there are many examples of partial wall collapse in these systems and a few examples of catastrophic collapse (see Kasthurba et al., 2007: Kasthurba et al., 2008) leading to permanent abandonment (Figure 3).

Thus, suranga are a classic gallery filtration irrigation system. The nomenclature of suranga is varied as a result of the cultural and linguistic diversity of the Dakshin Kannada and Kannada region (historical Kanara) where they are found. This region is made up of Tulu, Kannada, Malayalam, Konkani and tribal speakers and as such suranga are referred to by many other names including surangam, jal-thurangam, thurangam, thorapu and mala (Basak et al., 2005) to name but a few. The full geographical range where the technology is found is yet to be determined, but the major concentration of these systems is found in south Karnataka and northern Kerala (Table 1). To be more specific, the majority of suranga are found in the foothills of the Western Ghats of Dakshin Kannada district, Karnataka and Kasaragod district, Kerala. Recently suranga have also been constructed in Shimoga and North Goa districts respectively, a process of technological transfer that will be returned to later in the paper. The key point to raise here is that whilst in the context to India as a whole this is only a small area, regionally suranga are found over quite an extensive area, and in some locations in dense numbers, thus they are visible in the landscape.

Questions remain unanswered about the suranga system such as just how old it is, and from where does it originate? The next section outlines the methodology used to try and answer these specific research questions and addresses the limitations of the different approaches used in this semi-tropical context.

\section{Methodology}

To learn more about the origins of the suranga system we first examined documentary archives, before collecting oral testimonies from suranga farmers. Finally we attempted to date the origin of the system using a number of different natural archives.

The documentary archives available to us were limited mainly to colonial records, not least because Sanskrit and Kannada texts of the area rarely concern themselves with the nuances of farming and irrigation and the main local languages have no history of documentation as they are largely oral traditions. The main colonial archives examined for this project relate to the period of 
British Rule from 1799 CE. Canara or Kanara (historically consisting of Uttar Kannada, Dakshin Kannada, Udupi and Kasaragod districts) came under the British Madras presidency and thus historical manuscripts were consulted in Karnataka state archives, Vidhana Soudha, Bangalore and Tamil Nadu State Archives in Chennai. Detailed forest and irrigation records for the region collected by the British were also consulted. Portuguese colonial records from the $16^{\text {th }}$ century were consulted in the Goa archives in Panji to check the provenance of suranga in this region. One reason for doing this was also to investigate a potential route for technology transfer based on demographic movements in the area as an alternative route for the transmission of ideas about water control could also have come inland from the north as opposed to the Malabar Coast route. All of these accounts rarely tackled the mundane everyday existence of farmer and lower castes and tribals, so there is a dearth of information relating to the pre-colonial period.

Where possible we have also interviewed local experts, such as Dr Rakdhakrisha Bellaru (Linguist -Government College, Kasaragod) and Professor N. Shyam Bhat (Regional Historian -Goa University) to investigate the altern voices and perspectives on development in the South Kannada region and to help understand the migratory patterns of the region. This included talking to local leaders of Hindu temples in the region. Furthermore in Manila village an area rich with suranga, it was possible to consult the personal 'official' archive of Murva Mahabal Bhat, who was the former elected head of a group of villages and a member of local government. His documents included a $1905 \mathrm{CE}$ village settlement register that contained a map of Manila and an enumeration of different land, soil, agriculture and water resources. The same farmer was also able to provide court proceedings of land/water disputes, land leases and debt agreements.

The PANOS oral testimony methodology was used (http://panos.org.uk/our-work/ourmethodologies/voice/) to interview local land owners, their workers and coolies because of its recognition of the personal accounts of individuals based on different direct memories and experiences. All interviews were carried out in a field or home context by an Indian national although at times intermediary translators/guides were used to overcome local dialects. To date over 300 interviews have been carried out mainly in Dakshin Kannada and Kasaragod (2012-2014). Farmers to interview were identified through a number of key local informants and users of suranga that are noted for their local knowledge of the system. These included a water journalist, a local family that exclusively uses suranga as opposed to other water harvesting techniques, and a renowned suranga builder who claims to have constructed over 1000 suranga. The questions included asking people to date their farms and the suranga on their farms plus any suranga that they may have been involved in digging or maintaining. In respect to oral history these testimonies covered an age span of around two to three generations. Only in exceptional cases did family memory go beyond this.

Secondary data were used in a number of instances. These consisted of both published and unpublished reports of the Centre for Water Resources Development and Management (CWRDM) in Kozhikode. Besides this we conducted interviews with active researchers and NGOs operating in the region in the context to traditional irrigation including the Varanasi Research Foundation, the DHAN foundation (Development of Humane Action) in Madurai, Tamil Nadu and the Ashoka Trust in Bangalore, Karnataka.

Once completed we then looked to try and date the system using natural archives, however, it proved impossible to link the date of a storage pond (kere) associated with collecting and storing water from suranga to the date of the opening up of a suranga, as farm ponds are used in other water harvesting contexts. Beside this some of the analytical dating techniques (isotopic ${ }^{210} \mathrm{pb}$ and ${ }^{14} \mathrm{C}$ analysis) that we envisaged using on the basal sediments found in suranga conveyance channels and below storage ponds associated with existing 'old' suranga could not be used with any confidence because the systems are cleaned out regularly. Without sufficient layers of sediment it has, to date, proved impossible to conduct palaeo-ecological analysis. Dendrochronology was also attempted in order to try and date the origin of older arboriculture plantations in a number of locations, however, older trees identified in the field, like Mango and Jackfruit, have proved too difficult to distinguish the growth ring patterns. Likewise the identification of pottery lithics from different historical epochs has proved difficult because pottery is not widely used in this region. Overall the semi-tropical environment of the Western Ghats and the unremitting landscape of red laterite soils has made the identification of suitable natural archive sites suited to dating all but impossible to find. On top of this it is also almost impossible to distinguish provenance between the old and the new, as all carbon based materials like irrigation tools and wooden conveyance channels rot down quickly and or become recycled. In respect to the specific issue of dating suranga tunnels some suranga systems combine with natural cave systems, which make the dating of the tunnel materials inconclusive. 


\section{Results}

\section{Technical adaptation and logic}

Suranga in all but a few instances are built on short but steep slopes typical of the foothills of the Western Ghats of India. Typically suranga are associated with small farm units of an average size of around $1.8 \mathrm{ha}$, although these can be much larger or indeed smaller ( $0.3 \mathrm{ha})$. Where possible farm dwellings are constructed on levelled out terraces that can be as small as $1.5 \mathrm{~m} \times 4.5 \mathrm{~m}$ where arboriculture is practiced and intercropping is common. In a few locations larger ( $\sim 30 \mathrm{~m} \times 30 \mathrm{~m})$ levelled out terraces, usually located in flatter areas, are used for paddy, and the growth of vegetable crops, although this practice is less common than it was before 1980-85 when favourable market conditions for areca plantation resulted in their replacement (Bhat pers.comm.) . Water harvesting structures like small farm ponds (kere) are usually found on these terraces being fed by either an adjacent suranga or one found at a higher altitude. Usually at least one suranga is built close to the family home and used exclusively for drinking water. Water is typically channelled through small pipes under gravitational force, whereas in the past small open channels were used for distribution. This allows the natural pressure gradients from steep adjacent slopes to support spray irrigation, foggers and drip irrigation networks that are used on these slopes. Water allocation is calculated for individual crops based on their growth cycles and fruiting regimes. The majority of water goes towards areca plantation and coconut, whilst banana will also be irrigated.

Site selection for constructing suranga can be determined by water divination, eco-botanical markers, such as termite mounds and hydrophilic species found in the catchment recharge area and the structural properties of the laterite in a location. The laterite must be of a suitable strength to prevent tunnel collapse usually indicated by the lateral layering patterns and rock substrate. The dimensions of suranga in secondary data (Kokkal, 2002; Basak et al. 2005; Balooni et al. 2010) point to a range of lengths of between 3 to $300 \mathrm{~m}$. Data drawn from our independent survey of over 750 of these systems provides an average length of $33.08 \mathrm{~m}$, widths ranging from $0.45-0.7 \mathrm{~m}$ and heights ranging from $1.6-2 \mathrm{~m}$. The width and height basically match those of the labourer(s) who dug the suranga. The length in part is determined by the proximity of the phreatic water table to the slope. Where necessary the main conveyance channel in the tunnel will be bifurcated like fingers from a hand (kai) in order to change direction towards a more reliable water source or change direction as a response to hitting hard rock. Thus, extension to the tunnel length of a system is a commonly used strategy to enhance supply. The vast majority of suranga do not require air shafts to be built partly because they are short and it is often impractical to build airshafts in undulating hilly topography as heavy monsoon rainfall would make these structures vulnerable to collapse and liable to pollution during the rainy season. In only three instances, in what can be described as atypical flatter plateau topographical conditions, have we found evidence for longer suranga with vertical air shafts. Balooni et al. (2010) have also made reference to some suranga systems being two tiered, but upon inspection of some of these systems we discovered earlier higher suranga systems that had only after a short distance hit hard rock that were then mined underneath the initial point of entry to find water. This gives the impression of a double tier. Suranga discharges range from $0.005-0.1 \mathrm{~m}^{3} \mathrm{~s}^{-1}$. These discharges can be quite variable during the course of a calendar year, and seasonal drying up can occur.

Suranga provide niche habitats for insects, spiders, frogs, crabs, and turtles and a bat expert Dr. Suthakar Isaac (St Johns College) confirmed that suranga are providing new habitats to bat species, including Hipposideros ata and speoris. Aside from this snakes such as python (Python molurus) may live in suranga whilst snakes like cobra (naja naja) and occasionally king cobra (Ophiophagus hannah) will take shelter in suranga. Mammals like wild boar (Sus scrofa) and Indian crested porcupine (Hystrix indica) are also commonly found in suranga.

\section{Organisation}

The construction and maintenance of suranga is normally carried out by a paid labourer, amongst these there are examples of suranga builders who have become specialists (but with no family tradition) with one labourer (Kunjambu) claiming to have constructed $\sim 1000$ tunnels. No specialist knowledge is necessary for construction to occur as attested to by the large number of poorer scheduled caste or scheduled tribal peoples who have constructed their own suranga using small land grants from government in hilly land away from main water sources.

Suranga are constructed and owned by private individuals in relatively small but variably sized family units (generally $<8$ people) and there is no collective responsibility for these water 
supplies nor is water, like forestry, classed as a common resource. Thus, in all but a very few instances, there is no system of sharing of suranga waters except for drinking water suranga that can be shared by up to 3 families. These may be part of a joint family arrangement, neighbours or landowners and their workers. Maintenance is usually carried out by farm labourers. Typically a suranga will be cleaned once a year. Collapse or partial collapse may result in a small team of labourers working on shoring up a suranga tunnel if the risk is not too great of catastrophic collapse. In these instances abandonment will occur.

There are oddly no Hindu or Tribal rituals associated specifically with the building or maintenance of suranga unlike with other elements of the agricultural system. There can be a short blessing given for suranga used for drinking water. The number of suranga per farm unit is dependent on the owner and the supply and demand for suranga water on the land. There is no clear relationship between size of landholding and the number of suranga. Interestingly up until the last few years, and only in a few instances, have suranga been written into sale of land contracts, whereas wells, tanks and ponds were always mentioned in these documents.

The language and terminology used for the tools and practices associated with the suranga system are drawn from the multiple linguistic influences of the region described earlier. For the most part there is no specific distinction made with respect to tools used in suranga digging/construction or for different structural elements than those routinely used in other agricultural contexts. For example, kai used to describe branches in suranga systems is a word found in both Kannada and Malayalam languages. Indeed the name suranga is also a generic term used in most Indian languages to describe a tunnel or cave whereas other traditional water harvesting structures in the region like Katta and Madaka do have specific meaning.

\section{Arguments from silence}

Clearly one would also expect to find reference to suranga in official colonial irrigation records of the time if they existed, as it was typical to record both British irrigation projects alongside existing traditional Indian irrigation infrastructure. Buchanan's (1807) journey from Madras to the western Coast was the first ever detailed description of the Canara and Malabar region written in English. This did not report on any structure similar to suranga, but other local water management structures such as, Madka, Katta, and Kaidumbe were mentioned. More recently William Logan's (1995 reprint from 1887) account of irrigation infrastructure in Malabar in the 1880s makes no reference to suranga, but it does list traditional tanks. Thus, the question remains did suranga not exist then or were they just of too small a scale to warrant recording. Interestingly only up until the 1990 s have suranga appeared to have received any official recognition in either Karnataka or Kerala State records. Further to this the Imperial Gazetteer of India (1908, v. 14, p. 363) made reference to there being no government irrigation works in the district, but instead highlights the skilful utilisation of springs and stream by countless channels, feeders and temporary dams (known as kattas - see Balooni et al. 2008). It also talks of the use of substantial inland reservoirs at valley heads used to supply areca gardens. It does not, however, mention the use of suranga in the context to supplying these reservoirs. Moreover, there is no mention of suranga in Annual Settlement Records, and in Village Settlement Registers, while Kattas, springs, and tanks are mentioned and mapped.

To support this view it is necessary to turn to the archival evidence from forest archives, as it is these locations that most suranga are found in the context of inter-cropping and arboriculture. Forest archives emphasize that the area where suranga are now found was until British East India Company rule either natural tropical forest or scrubby secondary tropical forest (often referred to as wasteland) and it is apparent that the Dakshin Kannada region only became populated outside that of small transhumant tribal groups during this colonial period (Stebbing, 1922). Slash and burn practices (Kumari) were still common (although frowned upon by the British authorities) amongst tribal groups as attested to by both Cleghorn (1861) and Stebbing (1922). These forests, however, were a resource soon to be exploited, to their long-term detriment, mainly for colonial teak supplies and sandalwood (Balfour, 1849; Cleghorn, 1861). The timing and rate of peopling of this frontier forest location is thus crucial in understanding when suranga could have been constructed, as there is clearly no need for them at such low population densities and with a largely transhumant populace. A key date that may have acted as a catalyst for change is in 1837 when a new military road was constructed linking Mangalor to Mercara (Coorg) via Puttur (Gazetteer of South India, 1855:544) which is the area where the greatest density of suranga are found today. However Kakade (1949) comments that a large proportion of Puttur Taluk was covered with heavy forest and jungle on wastelands. Kumari was still practised in Kasaragod and Puttur Taluks suggesting that the slopes of laterite hills were not in many places permanently settled. 
Forest produce (e.g. honey, bees wax, soap nut [Shikakai] and myrobalan) rather than former natural forest and forest scrub in more marginal upland areas was outside the ownership and thus control of either colonial or Indian governance. This made it an exploitable frontier for those more marginal and poor in society. This surely would have proved an impetus for greater exploitation of the forest in this area, as population grew (Figure 4). At the same time improvements in forestry were being made and the Madras Forest Act of 1882 led to a growth and recovery in forest cover in the late $19^{\text {th }}$ century (Brandis, 1873).

The end of the British colonial period is marked by under cultivation of waste land that includes forests, it is also a time of major unemployment, such that the only growth in livelihoods is that what can be gained from existing land. It is perhaps not until the introduction of the 'Grow More Food' campaign in South India including South Canara between 1940-50 that new opportunities in agriculture arose (Kumar, 2005). Particularly as the practice of 'reserve forest' excluded local tribals from traditional settings, was reinforced in 1946 by the Madras Preservation of private Forest Act which resulted in increased non-tribal, that is, caste settlement of forest (see George and Chattopadhyay, 2001; Saravanan, 2011). Prior to this point as Kakada (1949:2) noted, agriculture was only practised close to the coast and the bottoms of innumerable valleys of rich alluvial soil, which wind among laterite hills and plateaus from the Ghats to the sea. Outside of timber exports the area was noted commercially for pepper production with a world monopoly established by 1940, however, declines in pepper export followed and new crops were needed to replace these. Cashew becomes a popular cash crop in the $20^{\text {th }}$ century, but is important to note that this crop is not irrigated. Likewise rubber that was introduced to the region in the first decades of the $20^{\text {th }}$ century is not irrigated. The main area of surangas falls outside that where tea growing became commercially important from the $19^{\text {th }}$ century (see next section). A more locally important arboreal crop was the areca nut (Areca catechu) and this crop does benefit from irrigation. Arecanut was abundant in 1855 (Gazetteer of South India, 1855:544), and was turned into a cash crop in the $20^{\text {th }}$ century in the region because of increased demand in the market, low maintenance in comparison to paddy, and higher return. Further to this areca becomes the plantation preference for Karhada Brahmin (Gao, pers.comm. 2013) whilst coconut a key component for local diets also requires irrigation. This shift towards perennial growth of arboreal crops often in replacement to rain fed paddy farming (Kumar, 2005) can only be achieved through irrigation. It is evident that this trend for areca production has followed through to the present with Balooni et al., (2008) observing this phenomena in the area over the past 40 years.

\section{Demographic and Economic factors}

Eighteen Karhada Brahmin families from Karhada in Maharashtra were moved under duress as a servile caste to the Kasaragod area in the $17^{\text {th }}$ century as part of a military movement linked to Nayak fort building (e.g. Bekal Fort) in the region. They were valued by the Nayak rulers as a religious and teaching order (Bellaru, 2001). They entered into the area of Tulu Nadu where tribal peoples and Tulu speaking Tuluva Brahmins had settlements in prime agricultural locations near to rivers. Thus, this particular southern branch of Karhada Brahmins had to seek new frontier land to settle on. At this point it is important to note that Karhada Brahmins were on the whole not farmers, as this inferred lower caste, so any movement into farming was protracted and long, not least because Janmie ownership inferred low caste. The reasons for this are that Janmie land ownership was misinterpreted by the British early during their reign (Buchanan, 1807). This resulted in the heightened power of Janmie owners and resulted in fragmented land holdings with little knowledge of tenants and subletting. The net result of this was inefficient farming and neglect of lower and slave casts. Besides this three sets of alternative tenures Kanan, Kulikanam and Verrumpattum also served to demote in status and dis-incentivise farmers and made for a stagnant land market. Such short and insecure tenure created an agricultural system under which new crops were rarely adopted. Only lower castes and agistic serfs farmed. It is known that many labourers $(\sim 30,000)$ from the Dakshin Kannada region were dependent on work in the rubber, tea and coffee plantations in the nearby Mysore, Coorg and Wynad regions in order to send back remittances to their families (Kakada, 1949:90). The other knock on consequence of these practices is that there was a shortage of labour in interior parts of Karkal, Puttur and Kasaragod especially in busy seasons. When the markets for these cash crops failed a sudden vacuum in local employment was created. Thus, from 1904-5 poorer farmers would have been incentivised to attach themselves to frontier Brahmin families, who were buoyed by access to the Agriculturalists loans Act VII 1884, and in the early days of agricultural and settlement expansion into the hills of South Kanara where most suranga are now found (Boag, 1933). A view supported by 
evidence from the first village settlement register for Manila village that was collated in 1905 (Murva Mahabal Bhat Pers. Archive).

What this means is that at some point in the 1940s the area had the antecedent preconditions for a minor agriculture take off with the introduction of new plantation crops that required irrigation. In this sense the southern branch of Karhada Brahmins are somewhat unique in that unlike most other Brahmins they have not retained any connection to the area of origin, outside that of their language, and some of the classic Brahmin rules of not working on the land have been relaxed and indeed lost over time. Interestingly Kakada (1949) also points to Haiga and Chitpavan Brahmins devoting themselves to the raising of arecanut plantation. However, their numbers were originally low and they moved into an area where population density was at first not great and at a time when water scarcity was not yet a major issue, as it was to become during the droughts of 1865-1866, 1876-1878, 1890 and 1899 (Prakash, 1988). The reason for this intense interest in this particular and specific group of Karhada Brahmins is twofold; first the Karhada Brahmins and their workers and coolies are today the main users of the suranga system, there is little use by Muslims as farming is not a favoured occupation; second the families and their workers moved exclusively into the villages today known as Padre and Bayar, the two villages where the highest density of suranga are found and claims to the oldest suranga made (Padre, pers.comm.). It is also important to note that other villages now with both notable numbers of Karhada Brahmin and suranga, like Manilla, are recorded for the first time during 1799-1860 (Bhat, 1998).

\section{Evidence from oral history and secondary data}

The paucity of data sources and written texts led us early to value the oral testimonies and histories of existing suranga farmers. Oral history to date at best puts the date of the suranga system back between 100-120 years ago 3-4 generations with the majority of the system even more recent than this. Somewhat ironically even the Kokkal (2002) report and Basak et al. (2005) make reference to these more recent dates of construction in context to Kanhangod block Panchayat and Kasaragod district respectively, as do Balooni et al. (2010) in their study of the Enmakaje panchayat. In all instances the point of inflexion and growth in the system, post 1940s appears to match the population increase for the time (see Figure 4). Our findings are congruous with these three independent accounts of origin. Nowhere is there any evidence for earlier structures outside of part semi natural cave systems with natural filtration galleries that may be older, such as the cave that bisects Posadigumpe in Bayar that can only be entered twice a year, but only in total darkness, because it is a sacred site and some similar systems associated with earlier temple construction. Another key element of these accounts of construction is that they are often motivated by individuals who have seen similar structures being built on neighbours land. Undoubtedly there are some individual families or workers who have a long history of suranga building, but at no stage do these individuals indicate that they received any kind of external intervention in terms of technical advice and/or motivation to dig these tunnels. So it remains a mystery who came up with the original idea for suranga and what that persons influences on this decision were? The next section describes earlier interpretations about the origins of the suranga system.

\section{Earlier interpretations of the origin of suranga}

Current academic discourse about the origins of this traditional technology is that suranga construction has been influenced to a large extent by qanat technology drawn from the Arabian/Persian Gulf region as a result of the long history of trade and movement of people and ideas between Malabar and Persia (English,1968; Kobori, 1973; Biswas, 1976; Kokkal, 2002; Kokkal \& Aswathy, 2009; Doddamandi, 2010). There is no doubting that there are large Muslim Mappila groups living in the area where suranga are found, but more particularly along the Malabar Coast of Kerala, arising as a result of the pre- and post-Islamic Arab trading contacts with the area. It is also undeniable that qanat can be found in northern India (Esfandiari, 2007) and Khooni Bhandara, which is a unique underground water management system developed by the Mughals in the seventeenth century in Burhanpur, Khandwa district, Madhya Pradesh (Nagda, 2001). The qanat system has been skilfully mapped (see Lightfoot, 2000; Asghar Semsar Yazdi \& Labbaf Khaneiki, 2010; Boualem \& Rabah, 2012) across the countries of the Levant and Maghreb and on into Spain to the west and into Afghanistan, China and Japan to the east using traceable etymological connections and conjunctions to a detailed and specific irrigation language and technology recorded in a written and ocular form. To this extent the suranga system appears quite unique, as other irrigation systems typically have their 
own language and terminology associated with the tools, procedures, laws and rituals associated with irrigation (Geertz, 1972; Guillet, 1987; Critchley, 1990; Crook \& Jones, 1999), so why are none found for suranga?

Many authors (Halemane, 2007; Kokkal \& Aswathy, 2009; Balooni et al., 2010) believe that suranga match the same model of irrigation as qanat. Basak et al., (2005:222) provide this analogy:

"The Centre for Water Resources Development and Management (CWRDM) in Kozhikode has found that the ancient technology of qanats is still in vogue in certain parts of Kerala for both irrigation and drinking water (Basak et al., 2005:222)."

This work was largely influenced by an unpublished 2002 report by Kokkal entitled 'Studies on development of surangams as a non-conventional water resource in the Kanhangad block panchayat', commissioned for the Centre for Water Resources and Development Management (CWRDM) that focused on suranga and other traditional water harvesting techniques.

Both qanat and suranga rely on gallery filtration collection methods and it is easy to see why parallels have been drawn between the two systems. Qanat historians can draw on lithic, artefact and building evidence associated specifically with qanat farming that are distinguishable and dateable (see Asghar Semsar Yazdi \& Labbaf Khaneiki, 2010 and 2012; Hu et al., 2012). In some locations qanats can be dated as far back as the first millennium B.C. and it has been argued that this longevity has contributed to habitat-specific variation in the life history of the fishes Capoeta fusca (Patimar \& Mohammadzadeh, 2011) and Alburnoides bipunctatus (Patimar et al., 2012). To date there is no phenological evidence for any similar long-term adaptation in either flora or fauna in the suranga system. As a result of this longevity religious/legal concepts, like the qanat bound, have also developed (Semsar Yazdi \& Labbaf Khaneiki, 2010), something that is not seen in the suranga system.

In terms of the technology qanat tunnels can run for kilometres as recorded by Balooni et al., (2010) and Semsar Yazdi and Labbaf Khaneiki (2012:27-31) in Iran, but the average lengths of suranga are much shorter. They are then more similar in length to some alfalaj found in Oman (Charbonnier, 2014) and the Arabian foothills and mountains of the Syrian Anti-Lebanon (Lightfoot, 1996). The actual tunnel dimensions of the suranga water conduit are similar to those described in many qanat which also have a human dimension. The construction of qanats typically requires specialists teams (Semsar Yazdi \& Labbaf Khaneiki, 2012) as opposed to the solitary labourer who will usually construct a suranga. The normal discharges of Iranian qanat are $0.0004-3.7 \mathrm{~m}^{3} \mathrm{~s}^{-1}$ with an average of $0.29 \mathrm{~m}^{3} \mathrm{~s}^{-1}$ (calculated using Semsar Yazdi and Labbaf Khaneiki, 2012 data: pp 27-31 $n=100$ ). This is an order of magnitude greater in some instances, but probably similar to discharges found in some of the smaller qanat systems. In both systems discharges can be quite variable during the course of a calendar year, and seasonal drying up can occur, in response owners often extend the length of a tunnel or build a new sub-branch to enhance supply(Asghar Semsar Yazdi \& Labbaf Khaneiki, 2010). Qanat builders also have a technique of mining underneath a conveyance channel (tahsoo-bonsoo) to increase flow (kaf sheqani). On a much smaller scale this technique has also been occasionally used for suranga.

In qanat, airshafts are often needed in longer conveyance channels for ventilation, although it is acknowledged that shorter simple source capture systems are also found without air shafts. There are numerous images and descriptions of qanat, alfalaj, karezes, foggara, kerez and so on (Lightfoot, 2000; Hussain et al., 2008; Asghar Semsar Yazdi \& Labbaf Khaneiki, 2010; Boualem \& Rabah,2012; Hu et al., 2012) that incorporate vertical air shafts moving down slope from a dug mother well (see Figure 5). The most often cited and replicated figure in respect to suranga having air shafts appears in Basak et al., (2005:222). Balooni et al., (2010:662) incorporate this image and claim to have found eight surangam with air shafts in Enmakaje panchyat. However, as described earlier, the vast majority of suranga do not require air shafts to be built partly because they are short and don't require ventilation. Thus, we conclude that the Basak et al. image from 2002 is not representative of the suranga system as a whole.

Qanat like most common property resources (Ostrom, 2000; Ostrom and Vollan 2010) and other traditional irrigation systems tend to have three types of collective action in participatory irrigation management ranging from constitutional rules, communal rules and regulations relating to function and operational actions. In the case of constitutional rules the ownership of water rights and the scheduling and allocation of these rights are usually in proportion to the personal or family contribution made towards the construction and annual maintenance of the system and or the size of land holding. Suranga are fundamentally different because they are privately owned and this source of water is not seen as a common property resource. 
Thus, a review of the available literature on qanats and suranga (English, 1968; Basak et al., 2005; Balakrishnan \& Saritha, 2007; Lightfoot, 2007; Kokkal \& Aswathy, 2009; Balooni et al., 2008 and 2010; Asghar Semsar Yazdi \& Labbaf Khaneiki, 2010 and 2012, Boualem \& Rabah, 2012 to list but a few) has failed to unearth any published hard evidence directly linking the two systems. This throws doubt over the date of origin of the suranga system, so in order to try and independently trace the origin of the suranga system a new hypothesis for the origin of suranga is suggested below.

\section{Discussion and new theory of origin}

The main tenet of our argument about the origin of suranga is based on a combination of evidence: first incongruence between key elements of qanat technology and suranga technology; second a marked silence (see Elvin \& Crook, 2003 for a similar argument) in respect to any written reference to the suranga system throughout early-modern colonial and Indian history; and finally a compelling oral history that references the start of the system to much more recent times.

The first point is that whilst there are some similarities between suranga and qanat technology in that they are both gallery filtration systems, the size and scale (Sankaran Nair, 2006) of the systems and their governance clearly point to more fundamental differences. This means that when seen in the field they are visually very different technologies found in contrasting environments and landscapes. Qanats are fundamentally a dry or semi-arid land technology whereas suranga are found in sub-tropical areas that are exclusively associated with laterite soils. Qanat are generally much larger than suranga and involve communal construction as opposed to the private construction and use associated with the majority of suranga. The depiction of air shafts in suranga has proved misleading, as air shafts are only found in exceptional circumstances where the terrain determines the use of long suranga ( $n=3$ in our study), which is in marked contrast to qanat systems that are for the majority dependent on the use of airshafts because of their length. It is accepted that there are a few short qanat without air shafts, but these are exceptions found more typically in Oman and the Arabian foothills and mountains of the Syrian Anti-Lebanon. Given that there is no identifiable connection to any of the areas where qanats exist in India to the area where suranga are found through human migration it is a very large step to make to imagine the idea being spread this way. Thus, if this argument is accepted there is no case for a transfer of technology and ideas to this particular region from Persia and the Arabian Peninsula.

However, there is still insufficient evidence to say definitively when the suranga system started, but it is possible to put forward a case for its inception based on an emergent demand for perennial irrigation of cash crops. This was driven by a growth in population that became more settled in a frontier region (e.g. Manila village) that was once characterised by forest 'wasteland' and shifting cultivation. This is borne out by the fact that the last Tiger to kill cattle in Manila was recorded in 1949/50. This overtime resulted in some deforestation followed by the development of plantation forestry as the availability of new cash crops like areca became the norm. Further to this and perhaps just as compelling an argument was that after post War Independence India really pushed for an improvement in sanitation and drinking water. Suranga in undulating terrain make it possible to construct latrines in or close to the home for the first time and make the access of clean drinking water easier, thus reducing the time needed to collect water, and freeing up labour. Suseelan (2009) demonstrated how this resulted in homes becoming divided between wet and dry activities. The inspiration for building the suranga seems to lie in the Karhada Brahmin community, but the evidence tells us that this propensity for change was evolutionary as this community evolved from a small largely religious and educational community to a larger and more diverse community that practised agriculture, contrary to typical Brahmin sensitivities about working the land, although it must be remembered that this community still today retains a large spiritual and educational role in the region through various temples and schools. This evolution in livelihood was long and may well have been crystallised by witnessing the quite horrific effects of drought in the region during the $19^{\text {th }}$ century (Prakash, 1988) and the desire to ensure that this doesn't happen again. In 1880 the Famine Commission did commission a Tank restoration scheme for the maintenance and improvement of petty irrigation work (Boag, 1933) To this extent it is perhaps an important point to note that often the greatest motivation for construction of suranga comes from the desire for reliable drinking water and not irrigation.

The step from an idea to a tangible technology is not hard to believe in a region where it was acknowledged in the early $20^{\text {th }}$ century that there were a large number of natural springs being exploited and where tunnelling for religious purposes was already well established. Given that the heads of these temples were and still are Brahmin, a channel of communication for these ideas is 
already there. What starts as a desire to increase the flow of an existing spring can provide the genesis of an idea to explore for new sources of water using a well-established lay knowledge on where to find water, something that Suseelan (2009:474) refers to as a natural model. Water divining and ethno-botanical identification are two well established ways of locating a place to start digging a suranga (Kokkal, 2002). On top of this the density of suranga found in the villages of Padre and Bayar, both locations where Karhada Brahmin settled, is probably facilitated by a large number of small natural springs in these locations. The fact that the local experts in Karhada Brahmin culture (Gao pers.comm.) have a propensity to favour the growth of areca plantation, alongside coconut, means that there are economic reasons driving the development of new suranga to allow for perennial cultivation dependent on irrigation and more secure livelihoods. Of course the Endosulfan tragedy in the 1980s in Kasarogod (Dewan, 2002) has also meant that more recently farmers have moved away from non-irrigated cashew cultivation and more into areca and coconut production alongside rubber plantation. In doing this they have adopted for the most part organic methods of farming. To this aim the self-regulated control of an uncontaminated water supply from suranga remains both reassuring and confident in a community where water and to some degree forest is not treated as a common and private concerns and demands are put first.

Thus, in conclusion whilst there is no definitive evidence from either natural or human archives for the origin of suranga irrigation we believe there is sufficient evidence to reframe the discourse of genesis around much more recent times 1900-1940 CE, and divorce the idea that there has been any direct influence from the qanat system from either Persia or the Arab peninsula or from the northern interior of India until such evidence can be found. The recent examples of transfer of technology to Shimoga (1990s) and Northern Goa (1980s) have arisen in the first instance as a result of an exposure to the system through a visit by the farmer to the Dakshin Kannada region and in the latter case as a result of marriage between a woman from the Dakshin Kannada region from a family with suranga with a man from Goa. Whilst the Shimoga farm unit is as far as we know unique, because the laterite conditions don't favour further expansion in Goa, the system has been expanded beyond this first family, as the laterite and topography here favoured suranga building to improve water supplies. This latter example shows clearly how the dissemination of ideas can occur quite rapidly amongst even unrelated farmers who have the inspiration to improve their livelihoods by adopting a new technology where the opportunity arises and communication between farmers are good. Thus, in our opinion, the origin of the system does not need to have come through any officially sanctioned idea or new technology, more its roots are most likely to be more organic. Thus recent calls to learn from the Iranian experience of qanats (Balooni et al., 2010:664) whilst an interesting exercise in comparison should not be seen as the blueprint for change and adaption in the suranga system.

\section{Acknowledgements}

We thank and are extremely grateful to Sue Rouillard at the University of Exeter for producing figures 1 and 2.

\section{Archives consulted}

India

Karnataka state archives, Vidhana Soudha - Madras catalogue - forest and settlement reports

Tamil Nadu State Archives in Chennai - Revenue, agriculture, and irrigation catalogue

Goa State Archive Panaji - Ponda

Murva Mahabal Bhat personal archive

$\underline{\text { UK }}$

British Library India Office Records and Private collection Madras

National Archive, Kew - Maps and Plans

Kew Gardens Archive - Madras Records

\section{References}

Ali Asghar Semsar Yazdi \& Majid Labbaf Khaneiki (2010) Veins of Desert, Iran Water Resources Management Company. 
Ali Asghar Semsar Yazdi \& Majid Labbaf Khaneiki (2012) Qanat in its Cradle volume 1,UNESCO International Centre on Qanats and Historic Hydraulic Structures Iran Water Resources Management Company.

Balakrishnan K. \& Saritha, S. (2007) Groundwater information booklet of Kasaragod District, Kerala State, Central Ground Water Board, Ministry of Water Resources, Government of India, Trivandrum, Faridabad.

Balooni K., Kalro A. H. and Kamalamma A.G. (2008) Community initiatives in building and managing temporary check-dams across seasonal streams for water harvesting in South India, Agricultural Water Management 95, 1314-1322.

Balooni K., Kalro A. H. and Kamalamma A.G. (2010) Sustainability of tunnel wells in a changing agrarian context: A case study from south India, Agricultural Water Management, 97, 659-665.

Basak P, Raghavendra Prasad PM and Sreedharan (2005) Western Ghats in Agarwal A and Narain, S. [Eds.] (2005) Dying Wisdom: Rise and Fall and Potential of India's Traditional Water Harvesting Systems. $4^{\text {th }}$ edition. Centre for Science and Environment, New Delhi p220-223.

Belluru, R (2001) Karhad Brahmins: Historical Background, Essay No 2 in Karad Rajata 2001. Translation by N. S. B. Bhat.

Bhat, N. S. (1998) South Kanara (1799-1860) A study in Colonial Administration and Regional Response, Mittal Publications, New Delhi.

Biswas, A.K. (1967) Hydraulic engineering prior to 600 B.C, Proceedings of the American Society of Civil Engineers 115-135.

Boag, G.T. (1933) The Madras Presidency 1881-1931Madras, printed by the Superintendent Government Press.

Boualem, R. \& Rabah, K. (2012) The foggara in the Arab world, Geographia Technica, (1), pp. 1-7 Brandis, D. (1873) On the description of forests in India, Transactions of the Scottish Arboriculture Society reprint from Ocean Highways 1872. p88-

Buchanan, F. (1807) A Journey from Madras through the Countries of Mysore, Canara and Malabar. East India Company, London.

Charbonnier, J. (2014) In the shadow of the palm trees: Time management and water allocation in the oasis of Adam (Sultanate of Oman), Proceedings of the Seminar for Arabian Studies, 44, pp. 83-97. Crook DS and Jones A M (1999) Design Principles from Traditional Mountain Irrigation Systems (Bisses) in the Valais, Switzerland: Implications for Sustainability. Mountain Research and Development. 19, 2, 79-99.

Critchley, W.R.S. (1990) How Africa's pastoralists catch the rain: Rainwater harvesting is nothing new to the people of the sub-saharan drylands, CERES 22, 41-45.

Das, S (2007). Laterite Monuments of India, CHS Newsletter, 77, 15-19.

Dewan A (2002) Environmental epidemiological study related to aerial spray of Endosulfan on cashewnut plantations in Kasarogode district of North Kerala, National Institute of Occupational Health, Ahmedabad.

Doddamani, R. (2010) Tapping water through tunnels: The Malnad way. Downloaded from the Indian Water Portal p69-74.

Elvin M and Crook D (2003) "An Argument From Silence? The Implications of Xu Xiake's Description of the Miju River in 1639" in WU Xiaoliang, ed., "Collected Essays on Chinese History in Honour of Professor Li Yan on His Ninetieth Birthday and Sixtieth Year of Teaching* Yunnan University Press, Kunming, Yunnan, China.

English, P. W. (1968) The origin and spread of qanats in the Old World, Proceedings of the American Philisophical Society, 112, 3, 170-181.

Esfandiari Omid (2007) Qanat; Iranian's Most Remarkable Ancient Irrigation System, International History Seminar On Irrigation And Drainage, Tehran-Iran May 2-5, IRNCID-ICID pp55-61.

Geertz, C. (1972) The wet and dry: traditional irrigation in Bali and Morocco, Human Ecology 1, 23-39. George, P.S. and Chattopadhyay, S. (2001) Population and Land Use in Kerala. In: Growing Populations, Changing Landscapes: Studies from India, China and the United States. National Academy of Sciences, Washington DC, pp 79-106.

Gol (2011) Census of India 2011, Government of India http://censusindia.gov.in/2011census/FindVillages.aspx Guillet, D. (1987) Terracing and irrigation in the Peruvian Highlands, Current Anthropology 28, 409430 . 
Halemane, H. (2007) Suranga a sustainable water resource. National Seminar on Water and Culture, Hampy, Belari District June 25-27.

Hussain, I., Abu-Rizaiza, O.S., Habib, M.A.A., Ashfaq, M. (2008) Revitalizing a traditional dryland water supply system: The karezes in Afghanistan, Iran, Pakistan and the Kingdom of Saudi Arabia Water International, 33 (3), pp. 333-349.

Hu, W.J., Zhang, J.B., Liu, Y.Q. (2012) The qanats of Xinjiang: Historical development, characteristics and modern implications for environmental protection, Journal of Arid Land, 4 (2), pp. 211-220.

Kakada R. (1949) Depressed classes of south Kanara (A socio-economic survey), Servants of India Society, Poona 4, India Office Library.

Kasthurba A.K., Santhanam M. and Mathews M.S. (2007) Investigation of laterite stones for building purpose fromMalabar region, Kerala state, SW India - Part 1:Field studies and profile characterisation Construction and Building Materials 21, 73-82.

Kasthurba A.K., Santhanam M. and Achyuthan H. (2008) Investigation of laterite stones for building purpose from Malabar region, Kerala, SW India - Chemical analysis and microstructure studies Construction and Building Materials 22 2400-2408

Kobori, I. (1973) Some notes on diffusion of qanat. Orient, 9, 43-66.

Kokkal, K. (2002) Studies on development of suramgams as a non-conventional water resource in the kanhangad block panchayat, Report on Project Conducted by Centre for Water Resources

Development and Management, Kasaragod district, Kerala, Ground Water Division, Kerala, Submitted to Centre for development Studies, Thiruvananthapuram, Kerala state, India

Kokkal K. \& Aswathy M. V. (2009) Traditional water resources in Kerala, in Proceedings of Kerala Environmental Congress, Centre for Environment and Development, Thiruvanathanapuram. P47-62. Krishnan, J. (2007) Enclosed waters: Property rights, technology and ecology in the management of water resources in Palakkad, Kerala. Wageningen Holland.

Krishnaswamy, J., Lele, S. \& Jayakumar, R. (2006) Hydrology and Watershed Services in the Western Ghats of India: Effects of Land Use and Land Cover Change. Tata McGraw Hill Publishing Company Limited, New Delhi.

Kumar, B.M. (2005) Land use in Kerala: changing scenarios and shifting paradigms, Journal of Tropical Agriculture 42 (1-2): 1-12.

Lightfoot, D.R. (1996) Syrian qanat Romani: History, ecology, abandonment, Journal of Arid Environments, 33 (3), pp. 321-336.

Lightfoot, D.R. (1997) Qanats in the levant: Hydraulic technology at the periphery of early empires Technology and Culture, 38 (2), pp. 432-450.

Lightfoot, D.R. (2000) The origin and diffusion of Qanats in Arabia: New evidence from the northern and southern Peninsula, Geographical Journal, 166 (3), pp. 215-226.

Logan, W.(1995) Malabar, 1, p. 191.(reprint New Delhi/Madras first publ. 1887) 194-9; 484-5 Nagda J (2001) Reviving khooni bhandara, Catchwater, 3, 5,

http://www.rainwaterharvesting.org/catchwater/oct2001/tradition.htm

Ostrom E. (2000) Governing the commons. The evolution of institutions for collective action.

Cambridge: Cambridge University Press.

Ostrom E. \& Vollan B (2010) Cooperation and the commons. Science 330 (6006): 923-24.

Padre, S. (2006) Don't dig down, India Together, http://www.indiatogether.org/2006/apr/env-

addabore.htm

Padre, S. (2008) A 'Gurukula' for surangas, http://www.indiatogether.org/2008/feb/env-suranga.htm Patimar, R., Mohammadzadeh, B. (2011) On the biological characteristics of Capoeta fusca Nikolskii, 1897 in eastern Iran, Journal of Applied Ichthyology, 27 (3), pp. 873-878.

Patimar, R., Zare, M., Hesam, M. (2012) Research article on the life history of spirlin Alburnoides bipunctatus (Bloch, 1782) in the qanat of Uzineh, northern Iran, Turkish Journal of Zoology, 36 (3), pp. 383-393

Prakash B. A. (1988) Agricultural backwardness of Malabar during the colonial period: an analysis of economic causes, Social Scientist, 16, 6-7, 51-76.

Sankaran Nair, V. (2006) India-centric Hydraulic Civilization of the Old World, Source: 
http://www.boloji.com

Saravanan, V. (2011) Colonialism and conservation: Commercialisation of forests and decline of tribals in Madras Presidency, 1882-1947, Journal of Forest Economics 17, 337-362.

Sutapa Das (2007) Laterite monuments of India, CHS newsletter No 77, 15-19.

Suseelan, A. (2009). Investigating the relation of a sustainable vernacular technique to settlement pattern. In Jan Feyen, Kelly Shannon, Matthew Neville(2009) (Editors) Water and Urban Development Paradigms: Towards an Integration of Engineering, Design and Management Approaches. CRC Press: London. 473-478 pp.

Thurston E. (1912) Omens and superstitions of southern India, Mcbride, Nast and Company, New York.

Thurston E. (1913) The Madras presidency with Mysore, Coorge and the associated states. The University Press. Cambridge. pp 65-66. 

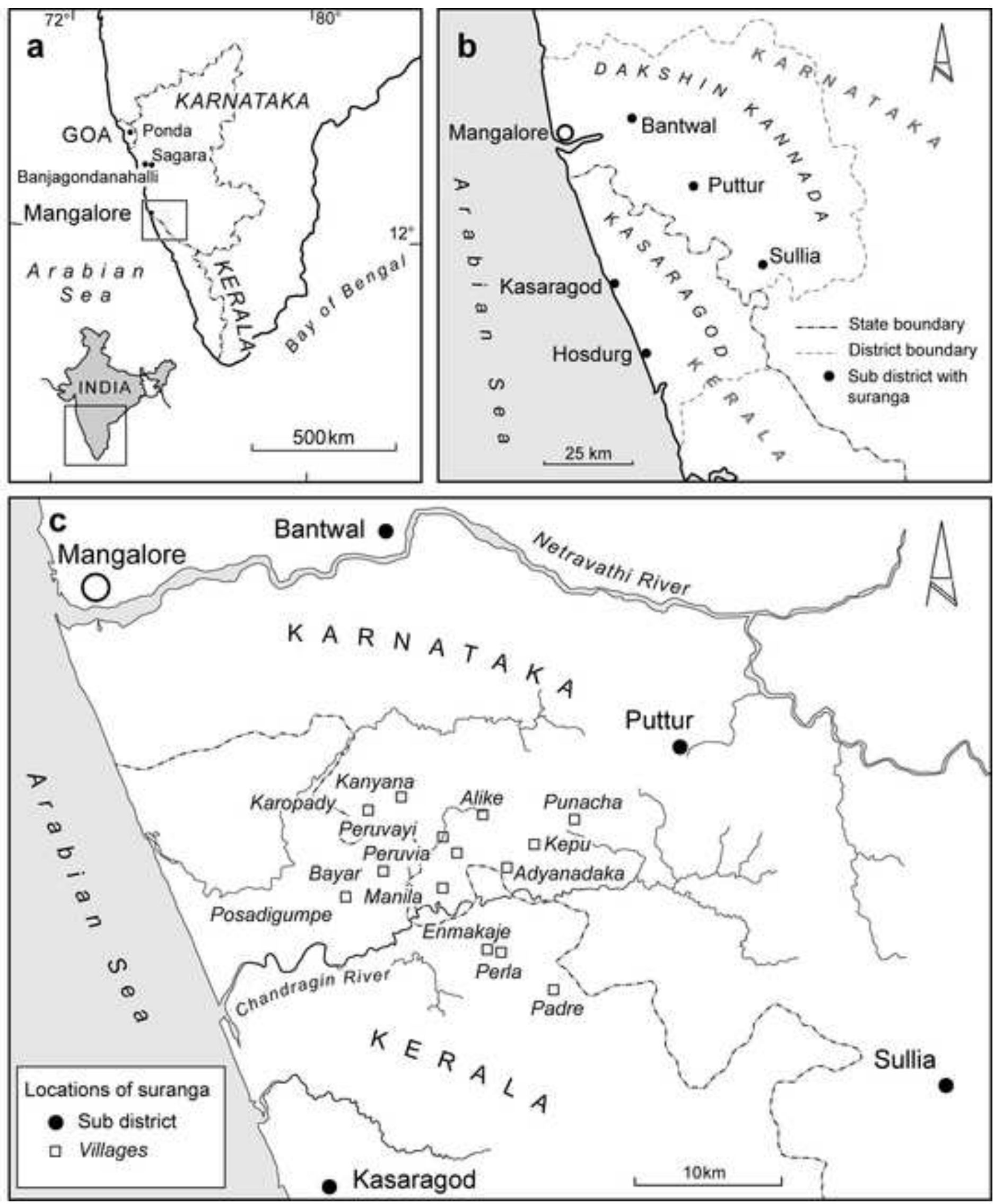


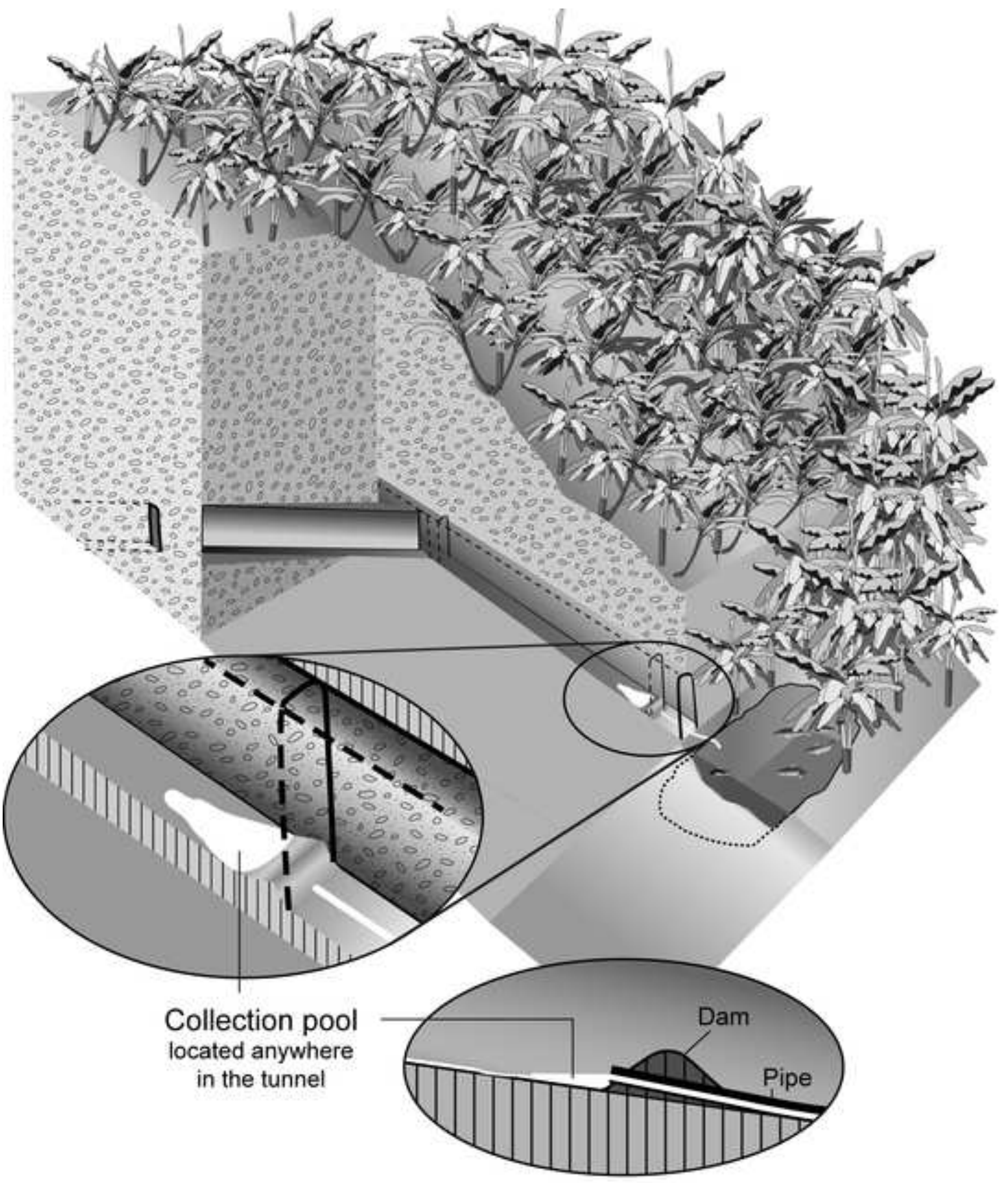


Click here to download Figure: Crook,Tripath\&JonesFigure 3.pdf

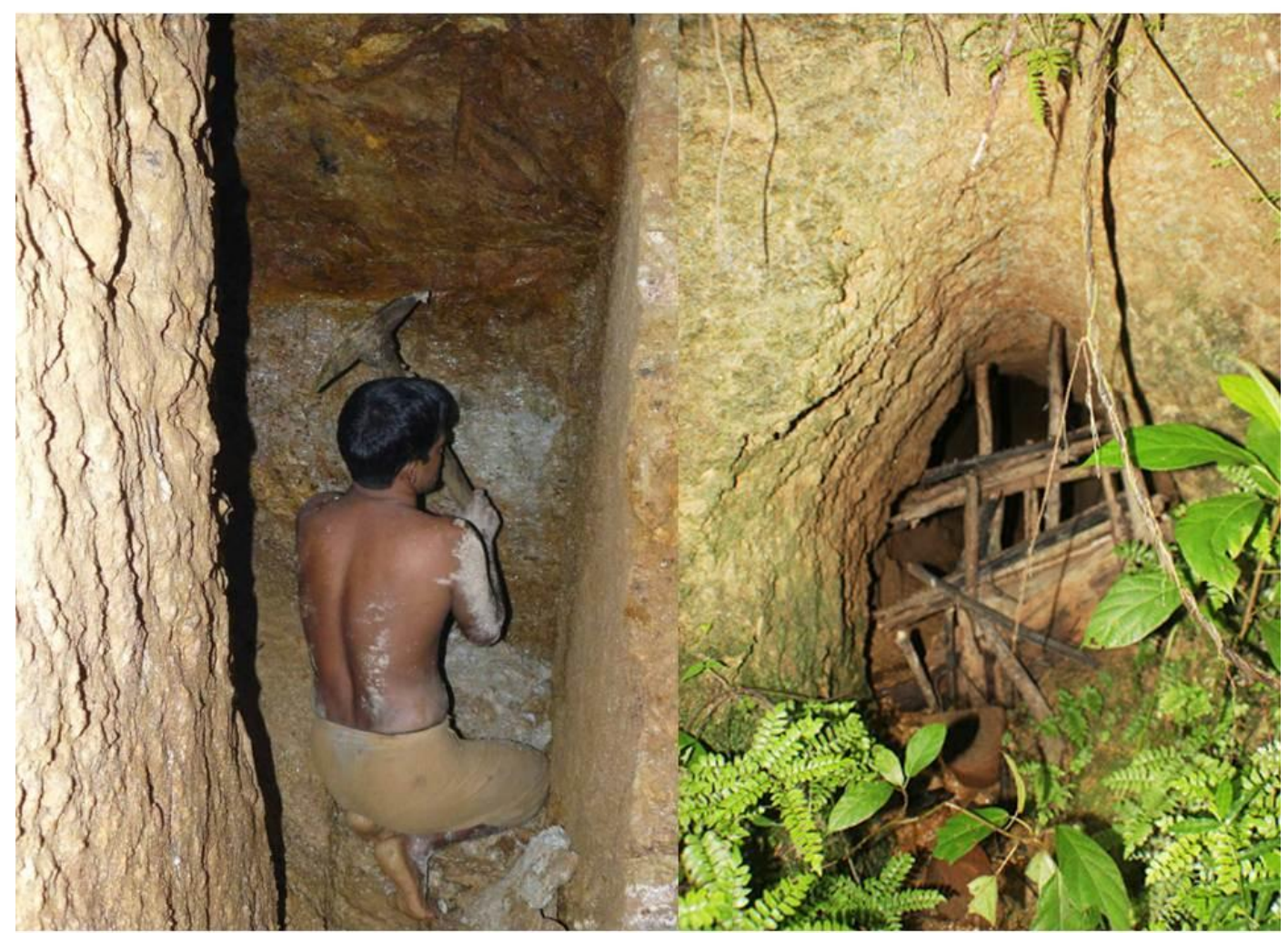




\section{Manuscript (without any authors' affilliations)}

Click here to download Figure: Crook,Tripathi\&JonesFigure 4.pdf

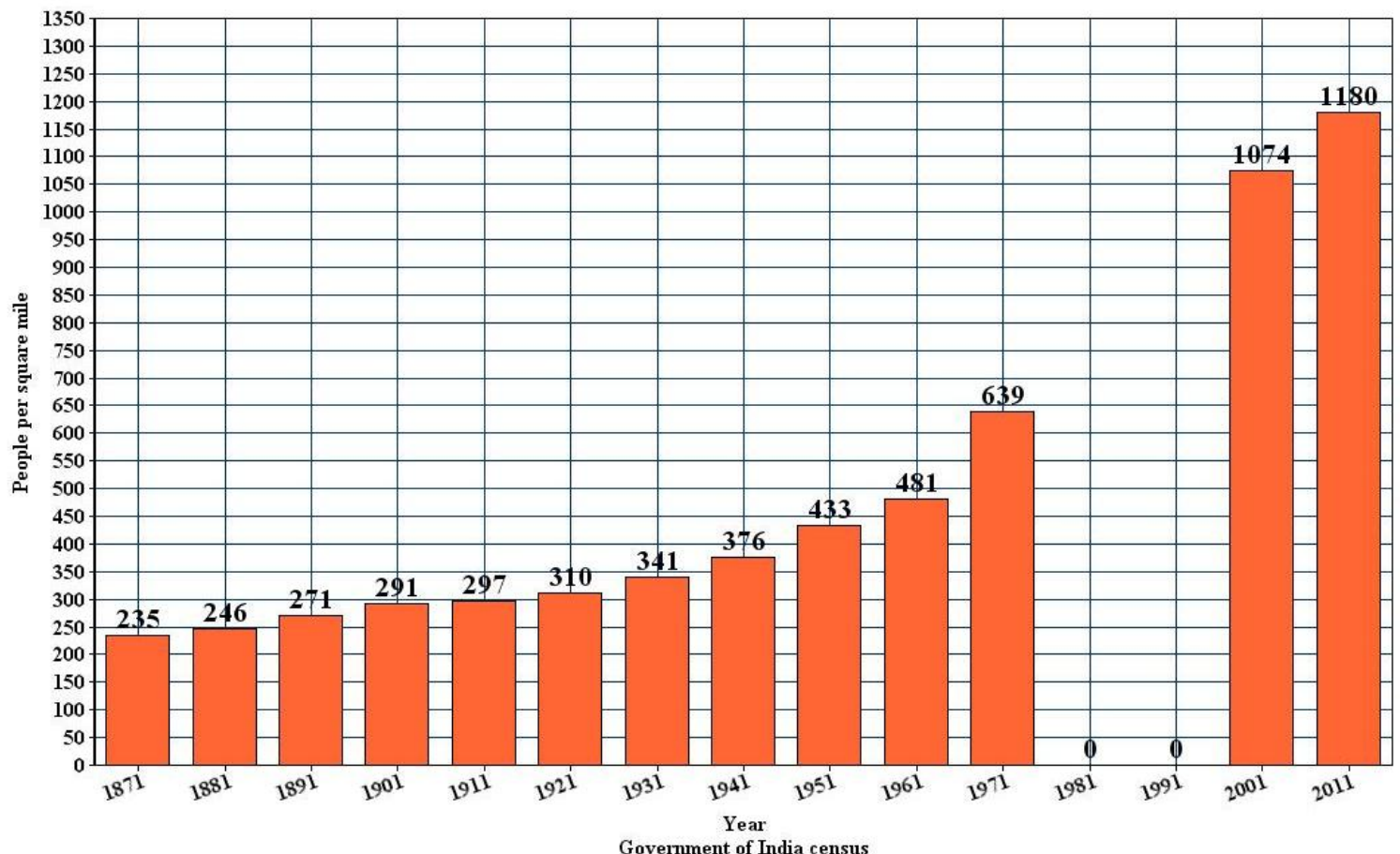

1981 and 1991 No data was collected 


\section{Manuscript (without any authors' affilliations)}

Click here to download Figure: Crook,Tripathi\&JonesFigure 5.pdf

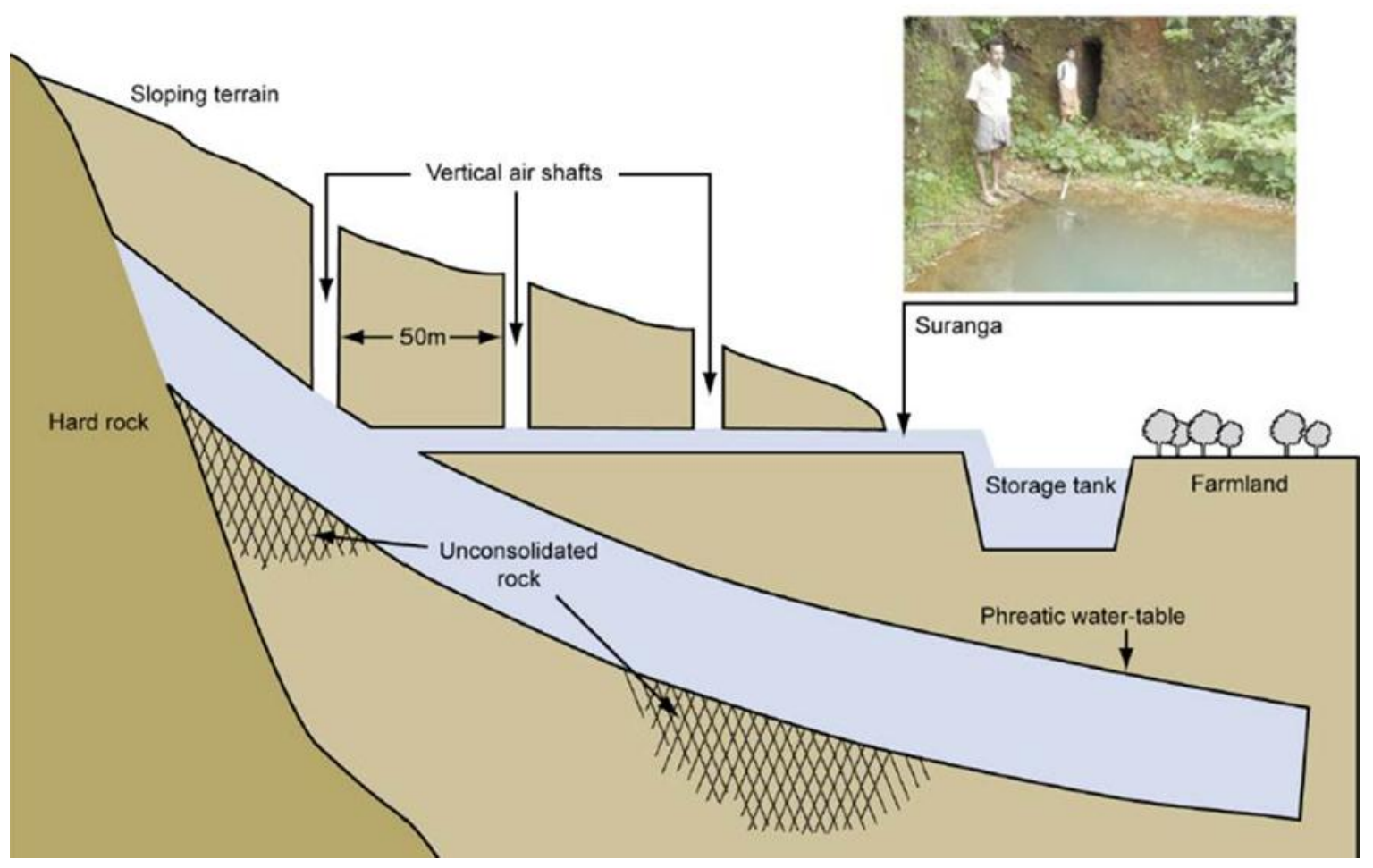


Click here to download table: Crook,Tripathi\&JonesTable 1.doc

\begin{tabular}{|c|c|c|c|}
\hline State & District & Sub-District & Villages (estimated no. of suranga) \\
\hline \multirow[t]{4}{*}{ Karnataka } & \multirow[t]{3}{*}{$\begin{array}{l}\text { Dakshin } \\
\text { Kannada }\end{array}$} & Bantwal & $\begin{array}{l}\text { Manilla ( 300), Peruvai } \\
\text { Alike, Kanyana, Keropady, } \\
\text { Kepu, Punacha }\end{array}$ \\
\hline & & Sullia & 4 \\
\hline & & Puttur & 8 \\
\hline & Shimoga & Sagara & Banjagaru (4) \\
\hline \multirow[t]{2}{*}{ Kerala } & \multirow[t]{2}{*}{ Kasarogod } & Kasaragod & $\begin{array}{l}\text { Bayar, Possadigumpe ( 2000), } \\
\text { Enmakaje (panchyat), Adyanadaka, } \\
\text { Perla, Padre }\end{array}$ \\
\hline & & Hosdurg & $\begin{array}{l}\text { Kahnangod Block panchyat (5 } \\
\text { villages) }\end{array}$ \\
\hline Goa & North Goa & Ponda & Priol (12) \\
\hline
\end{tabular}


Figure 1: The districts of Dakshin Kannada, Karnataka and Kasaragod, Kerala with key place names mentioned in the text indicated

Figure 2: A Suranga in cross-section (@Sue Rouillard)

Figure 3: Suranga under construction (L) and an abandoned suranga (R).

Figure 4: Population density in Dakshin Kannada for the duration 1871-2011

Figure 5: A Suranga system: image adapted from Basak et al., (2005:222)

Table 1: The spatial distribution of Suranga 